\title{
Research in Clinical and Experimental Surgery
}

\author{
Irami Araújo Filho* \\ Department of Surgery, Federal University of Rio Grande do Norte, Brazil
}

Submission: January 11, 2018; Published: April 10, 2018

*Corresponding author: Irami Araújo Filho, Biotechnology at Potiguar University-Laureate International Universities, Natal, Rio Grande do Norte, Full Professor, Department of Surgery, Federal University of Rio Grande do Norte. Potiguar Universities, Brazil, Email: irami.filho@uol.com.br

\section{Introduction}

We have to agree that the research represents the backbone for the development of surgery. Research in surgery, developed by a multidisciplinary team of researchers and support staff, focused on prevention and relief of human suffering by surgical disease. The way to achieve this is through the use of patientcentered outcomes research. The researchers focused on the patient using the critical evaluation of data to identify the best evidence to guide patient care in the real world. Researchers are interested in how various procedures influence the health of the patient in terms of functional capacity and quality of life [1]. Once identified best practices, surgeons researchers or academic surgeons, basic research, clinical research, work with good sense to, sooner or later, make them reality for all surgical patients. However, our reality is that incentives and encouragement for research are scarce, one of the reasons that cause the vast majority of Brazilian surgeons devote themselves exclusively to outreach activity, both public and private hospitals, College students or not [2]. It must be recognized that to perform relevant research, good quality and based on the scientific method demands time, too much teamwork and no financial return most of the time. Three magic words are essential for the research activity: interest, love and dedication.

\section{Developing the Research Interest in Surgery/Gastroenterology and Hepatology}

The interest in surgical research has been a decisive factor in surgical advances observed over time, since it represents the key to the progress of surgical Sciences. How to stimulate interest in research? This is the critical issue that needs to be answered in order to achieve the best possible participation. We must believe that mixing the interest in research with the results which flow from demonstrates the benefits of surgical Sciences Research and patient care. In addition, emphasize the importance of the interest in scientific research in Surgery and services meetings in Brazilian and International Congress of Surgery represents the best way to position your prominence among all participants2.
Knowing that research is the basis for evidence-based medicine, makes it clear that the interest in the research and its results facilitates the understanding and application of evidence-based principles. In this sense, then, the interest in research becomes of paramount importance. The research groups or, in a broader setting, departments and services, must increasingly act in an integrated manner in their efforts in the area of research, working in collaboration with other departments, services and schools of medicine. Senior researchers present at surgery services must insist on stimulating the youngsters and offer expertise in research design, methodology, data collection and analysis of primary and secondary complex data. Work in the use of techniques to innovate and translate research findings into real-world process of surgical activity. To sustain the vision of new surgeons, the training of the next generation in research is of fundamental importance[3]. It is perfectly feasible and doable associate assistance and research activity from the residency to the battle for survival in the professional life. It is difficult, but possible and should be encouraged.

Surgery services need as assumptions: - VISION of leadership in the prevention and relief of human suffering due to surgical disease; MISSION - to advance the surgical patient care through multidisciplinary research, focused on results and to train the next generation of surgeons and researchers. - Develop VALUES education culture together with the staff of the hospitals and research in the Faculty of surgery University departments; transforming innovation arising from the research in improving surgical procedures and conduct; ensure education and research in surgery for the next generation and these premises go through ethics [3].

\section{Research in Experimental Surgery}

The laboratory of experimental surgery remains important and even indispensable in the faculties of medicine, fundamental piece in the evolution of surgery (since the time of Claude Bernard, Alfred Blalock and many others), both to test new 
surgical techniques, new materials and medicines, and training and learning. The essential character of the laboratory of experimental surgery in medical schools has been increasing relevance in the century of information technology, because it is the speed with which emerge new procedures, equipment and biocompatible materials for use potential in surgery. The appearance of video endoscopic surgery, robotics and other technologies become more and more relevant to use of the laboratories of experimental surgery to better understanding of pathophysiological mechanisms of disease, undertake therapeutic trials with new drugs, studying biological markers and evaluate these new techniques with prospects for applicability of the human species [1]. All this has triggered, throughout history, ethical reflections, bioethical, philosophical and religious directed to research in vertebrate animals.

\section{The Use of Animals in Experimental Surgery}

The use of animals in scientific research laboratories is a dilemma that has caused some of the largest conflicts in every debate on bioethics. The principle of ethical experimentation with animals, known as the three " $\mathrm{R}$ " principle, proposes reduction of the number of animals used in each experiment, refinement of experimental techniques in order to avoid unnecessary pain and suffering and replacement, replacement by alternative methods, whenever possible. Without doubt, this is a concern of counselors of experimental work and academic surgeons who have used technological refinements in the design of experimental models, resulting in reduction in the number of animals and experimental groups. In this context, researchers should, before thinking about the real need of a biological model with animals, ensure the relevance of the study before deciding to propose a project involving animals. However, the reduction in the number of animals in research must not compromise the surgical detection and interpretation of biological effects and shouldn't lead to the repetition of experiments. The study design and sample size calculation, the control of variables, the statistical hypothesis tested, the choice of the statistical test used for data analysis and interpretation of results contribute to the refinement, enabling more information without increase the number of animals used.

\section{Ethics in Research}

Essentially, the surgical research ethics refers to the application of reasonable behaviour to the best moral care with people and animals, as well as the development and implementation of good laboratory practice in the execution of experimental studies. To perform a surgical research sound and acceptable, the surgeon must adhere to the ethics of discipline. Performed with the most appropriate scientific methodology available, good research involves a series of steps-the design of a project with the objective to answer the relevant question, the care with the experimental subjects and the proper interpretation of the data. The consummation of these stages of surgical research allows science and ethics to collaborate closely, and, consequently, better results. The Brazil has currently own legislation laying down rules for research on human beings (resolution 466/2012) and animals (Law No. 11,974/2008 and respective Normative Resolutions) [1]. Without research, the many advances found in the surgery would not have been possible in the way as we see them today. The research allows more accurate knowledge, information, new discoveries and innovative elements and possibilities for better treatments. Without research would not be able to help the thousands, millions of patients who benefited so far from the conquest of the evolution of the diseases that affect them. Without research, stagnation in medicine and in surgery would rule at all times. Patients and doctors would not have the same knowledge and possibilities for treating diseases. The research, then, is essential to medicine in General and even more so for the surgery. Discovery and validation are two of the most critical developments that emphasize the importance of research. The search can be considered to be the force that drives innovators and explorers who want to advance in the understanding of disease in the surgical world [2].

\section{Developing ideas for New Research in Surgery/Gastroenterology and Hepatology}

Where are the ideas? What are the factors that stimulate the idea of research? When the researcher neophyte from a graduate program stricto sensu and leaves the interest in research and the multiplier effect of the know-how acquired, it is natural that at your home institution is encouraged to develop studies on same line of your research advisor. Ideally, if you choose one or more lines of research, avoiding work in random studies. Following a line, it is very likely that a job stays with the question not fully answered, generating new questions and new research4. Who cares about this activity is always attentive to questions not fully answered in the work that reads, in discussions in the forums, research on surgical area Congress, discussions in formal or informal meetings, rounds where naturally emerge new ideas and the feasibility of cooperation to further investigation. It is essential to be created an environment and a research group on the services or in the departments of surgery, it will be important to generate ideas and put them into evidence. Is an important activity, pleasure and contributes to learn to think and generate knowledge.

\section{Write and Publish the Results of Research in Surgery}

Nothing more satisfying to the researcher than seeing your product research accepted for publication and published in a journal indexed. We must recognise the essential elements of the research, gather and report the data consistently and smart as critical elements in writing, to the success of the publication. Writing a research paper is a demanding process that young surgeons are often ill-equipped to address, which is very natural and predictable. The help of more experienced researchers in 
writing of the scientific work is always important and welcome. Consists of many complex tasks and the inevitable difficulties that confront each researcher. Residency programs should give more attention to cultivate writing skills, especially in the scientific field. Notes that the residence programs require residents to submit a final project, which, if it was done with data from patients or animals, compulsorily were approved by a Commission or Committee of ethics in research and, by law, publication of results is mandatory. Unfortunately, these works are rarely published [1-3]. The Advanced Research in Gastroenterology \& Hepatology will play a key role in high international visibility, indexed in several national and international indexes, is available to all surgeons and clinicians in this particular area of health to disseminate their research in a multi and interdisciplinary way, an important means of dissemination in the academic community worldwide. Those who want to join the surgical research groups, in hospitals or in laboratories of experimental surgery must demonstrate not only that can give good answers to relevant questions, but also can and should report clearly and effectively its results so that are useful for their peers.

\section{References}

1. Schanaider A, Silva PC (2004) Uso de animais em cirurgia experimental. Acta Cir Bras 19(4): 441-447.

2. Damy SB, Camargo RS, Chammas R, Figueiredo LF (2010) Fundamental aspects on animal research as applied to experimental surgery. Rev Assoc Med Bras 56(1): 103-111.

3. Toledo-Pereyra LH (2009) Importance of medical and surgical research. J Invest Surg 22(5): 325-326.

4. Toledo-Pereyra LH (2011) Developing the research idea. J Invest Surg 24(3): 101-102.

\section{Your next submission with JuniperPublishers will reach you the below assets}

- Quality Editorial service

- Swift Peer Review

- Reprints availability

- E-prints Service

- Manuscript Podcast for convenient understanding

- Global attainment for your research

- Manuscript accessibility in different formats

( Pdf, E-pub, Full Text, audio)

- Unceasing customer service

Track the below URL for one-step submission

https://juniperpublishers.com/online-submission.php 